OPEN ACCESS

Edited by:

Kostas N. Priftis,

National and Kapodistrian University

of Athens, Greece

Reviewed by:

Levent Dalar,

Istanbul Bilim University, Turkey

Manuel Sanchez-Solis,

Hospital Universitario Virgen de la

Arrixaca, Spain

*Correspondence:

Cláudia Schweiger

causch@hotmail.com

Specialty section:

This article was submitted to

Pediatric Pulmonology,

a section of the journal

Frontiers in Pediatrics

Received: 21 September 2019 Accepted: 20 March 2020

Published: 15 April 2020

Citation:

Schweiger C and Manica D (2020) Ongoing Laryngeal Stenosis:

Conservative Management and

Alternatives to Tracheostomy.

Front. Pediatr. 8:161.

doi: 10.3389/fped.2020.00161

\section{Ongoing Laryngeal Stenosis: Conservative Management and Alternatives to Tracheostomy}

\author{
Cláudia Schweiger ${ }^{1,2 *}$ and Denise Manica ${ }^{1}$ \\ ' Otolaryngology Department, Hospital de Clínicas de Porto Alegre, Porto Alegre, Brazil, ${ }^{2}$ Programa de Pós-Graduação em \\ Saúde da Criança e do Adolescente, Universidade Federal do Rio Grande do Sul, Porto Alegre, Brazil
}

Background: Following tracheal intubation, some children may develop stridor, which is an indication of an obstructive lesion in the airway, such as an ongoing laryngeal stenosis (LS). This review focuses on evaluation of stridor and possible endoscopic predictors of progression to LS and, once post-intubation acute lesions are established, therapeutic choices to manage this disorder in avoidance of tracheostomy. Tracheostomy, due to its inherent increased morbidity, mortality and influence on social stigma, should be viewed only as a last resort. In this article, available conservative and alternative therapies for ongoing LS are thoroughly reviewed.

Methods: A systematic review concerning randomized clinical trials and prospective studies on treatment modalities for LS was performed. A search strategy was developed for MEDLINE comprising terms related to disease, intervention and population. Title and abstract from captured references were peer-reviewed for eligibility. Selected studies full-texts were peer-reviewed and the results were compiled in a structured and narrative review. Stridor evaluation and post-extubation acute lesion classification were studied. Treatments such as balloon dilation, rigid dilation, corticosteroid-coated small tube intubation, and corticosteroid nebulization were described and evidence supporting their usage was discussed.

Keywords: airway stenosis, larynx, acute lesions, intubation, laryngoplasty

\section{INTRODUCTION}

Laryngeal stenosis occurs mainly as a consequence of endotracheal intubation. Endotracheal tube induced mucosal injury is a well-recognized etiopathogenic factor leading to stenosis but contributing factors are still a matter of debate. Among these, sedation level (1) and length of intubation (2) have already been demonstrated as definite risk factors.

Definition of acute lesions comprises those identified in $<30$ days since extubation $(3,4)$. Moderate to severe lesions pose the highest probability of progressing to chronic stenosis. Recently a classification for acute lesions was proposed with high sensitivity and specificity for the development of laryngeal stenosis. This classification is showed in Table 1 (5).

Endoscopic treatment of acute lesions may avoid eventual tracheostomy and need for open surgery; or result in a less obstructive lesion that may present a better probability of success for a following intervention.

A range of different endoscopic approaches can be used, both isolated or combined. The use of endoscopic treatment is resurging and this can be attributed to the availability of new and 
TABLE 1 | Classification of acute laryngeal Injuries (CALI) as mild, moderate, or severe, according to anatomical location and type of injury.

\begin{tabular}{|c|c|c|c|}
\hline & \multirow{2}{*}{$\begin{array}{l}\text { Group } 1 \\
\text { Mild }\end{array}$} & \multicolumn{2}{|c|}{ Group 2} \\
\hline & & Moderate & Severe \\
\hline Supraglottis & $\begin{array}{l}\text { Sdema } \\
\text { Hyperemia }\end{array}$ & & \\
\hline Glottis & $\begin{array}{l}\text { Edema } \\
\text { Hyperemia }\end{array}$ & $\begin{array}{l}\text { Uni- or bilateral ulceration } \\
\text { Arytenoid GT }\end{array}$ & $\begin{array}{l}\text { Inter-arytenoid } \\
\text { ulceration } \\
\text { Inter-arytenoid GT } \\
\text { Immobility }\end{array}$ \\
\hline Subglottis & $\begin{array}{l}\text { Edema } \\
\mathbf{0} \text { Hyperemia }\end{array}$ & Partial ulceration $\left(<360^{\circ}\right)$ & $\begin{array}{l}\text { Complete ulceration } \\
(3,600) \\
\text { GT }\end{array}$ \\
\hline
\end{tabular}

GT, granulation tissue.

more sophisticated endoscopic instrumentation and the adjunctive use of new pharmaceuticals (6). Besides, endoscopic treatment results in a shorter operative time, decreased length of hospitalization, avoidance of external incisions, and less emotional and financial burden on the family.

Despite important advances in the management of subglottic stenosis over the last decades, its treatment remains complex and challenging. The aim of this systematic review is to identify current available endoscopic approaches for this disease and evaluate their success rates.

\section{METHODS}

\section{Information Sources and Search Strategy}

We have performed a comprehensive systematic review in order to identify all reports concerning ongoing laryngeal stenosis and therapeutic strategies. Search strategy was developed for MEDLINE and comprised terms defining laryngeal stenosis and related disorders, and available therapies. Annals from major international meetings in otolaryngology and pediatric airway surgery were also consulted. We have also hand searched references from all retrieved publications and prior systematic reviews. The search strategy for MEDLINE is available in Table 2. Further search strategies followed the same structure.

Duplicates were excluded before proceeding to study selection. All titles and abstracts retrieved were screened independently by two researchers. Full-text articles also had its eligibility evaluated by two independent researchers. The last date of the search was July 7th, 2019. We have followed Preferred Reporting Items for Systematic Reviews and Meta-Analyses (PRISMA) statement for conducting this study and reporting our results $(7,8)$.

\section{Eligibility Criteria Inclusion Criteria}

We have included all references concerning randomized clinical trials (RCT), phase I and II prospective studies, case series and case reports, involving neonatal (0-28 days old) and pediatric (29 days to 18 years) patients, and reporting results on pharmacologic
TABLE 2 | Search strategy for MEDLINE (accessed: 07/07/2019).

\begin{tabular}{|c|c|}
\hline Search term & $\begin{array}{c}\text { Number of } \\
\text { entries }\end{array}$ \\
\hline $\begin{array}{l}\text { \#1: } \\
\text { (“Laryngostenosis"[Mesh] OR "laryngeal stenosis"[tw] OR } \\
\text { "subglottic stenosis"[tw] OR "laryngeal stenosis"[All fields] OR } \\
\text { "subglottic stenosis" [All fields]) OR ("stridor" AND "intubation" [All } \\
\text { fields]) OR ("acute laryngeal stenosis" [All fields]) }\end{array}$ & 4,192 \\
\hline 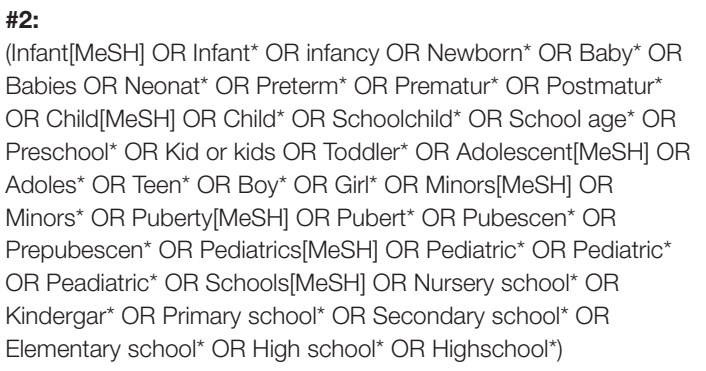 & $4,582,304$ \\
\hline $\begin{array}{l}\text { \#3: } \\
\text { (corticosteroid[tw] OR steroid[tw] OR balloon*[tw] OR dilat*[tw] OR } \\
\text { rigid*[tw] OR "Mitomycin"[Mesh] OR "1a-docosahexaenoyl } \\
\text { mitomycin C" [Supplementary Concept] OR "mitomycin C-N } \\
\text { (2)-deoxyguanosine adduct" [Supplementary Concept] OR } \\
\text { "mitomycin C-DNA adduct" [Supplementary Concept] OR } \\
\text { "mitomycin C-immunoglobulin M antibody conjugate" } \\
\text { [Supplementary Concept] OR "mitomycin C-dextran" } \\
\text { [Supplementary Concept] OR "mitomycin C-anti-alpha-fetoprotein } \\
\text { antibody conjugate" [Supplementary Concept] OR mitomycin[tw] } \\
\text { OR "cricoid split"[tw]) }\end{array}$ & 543,280 \\
\hline \#1 AND \#2 AND \#3 & 428 \\
\hline
\end{tabular}

and endoscopic treatments as primary approaches for ongoing laryngeal stenosis. Only reports in English, Portuguese, Spanish, Italian and German were eligible.

\section{Exclusion Criteria}

We have not included other types of publications such as reviews, editorials, letters to the editor, guidelines, study protocols or position papers. All open surgical approaches (even if endoscopic procedures were performed as adjunctive treatment) were excluded. Also, studies pertaining to population samples concerning adult patients (both exclusively or alongside pediatric patients) were excluded. Congenital stenosis or those acquired by other causes not associated with endotracheal intubation were excluded because they do not share the same pathologic mechanisms.

\section{Study Selection and Review}

Two reviewers participated in the screening and full-text evaluation. All abstracts screened and articles selected were reviewed by the same two reviewers, while a third reviewer would intervene if there was any discordance over eligibility. Reports were classified based on their main focus, whether diagnosis, prognosis, treatment and complications. All reviews were proceeded independently, and final drafts from both reviewers were eventually compiled into one final review article. 


\section{RESULTS}

\section{Search Results}

The initial search resulted in 432 references. After excluding duplicates and articles not concerning study's population and/or intervention, 106 were eventually assessed as full text. Finally, 22 articles fulfilled eligibility criteria and were included in qualitative synthesis. No quantitative meta-analysis of data was possible due to heterogeneity of interventions and scarcity of comparative trials. Studies content was summarized below. PRISMA flow diagram is depicted in Figure 1.

\section{Elective Endotracheal Intubation}

Hoeve et al. described 23 patients with a mean age of 37 days who presented extubation failure due to acute laryngeal lesion. They were re-intubated with a "loose fit" tube (inferior in diameter to what would be recommended concerning patient age, permitting leakage of air at the end of an insufflation) for a period of 17 days. Only one of these patients progressed to tracheostomy. When the airway finding was edema or superficial lesions, mean time for intubation was only 8 days and more than half of these patients were extubated within 3 days. When ulceration and edema was found, the mean intubation time was 13 days. However, when granulation was present, intubation longed for weeks afterwards (9).

Graham reported 10 newborn patients undergoing a protocol of 2 weeks of intubation after extubation failure due to acute lesion. Six patients were successfully extubated; two were tracheostomized and decannulated afterwards, with no need for further surgical procedures; one underwent tracheal reconstruction; and the other tracheostomized patient died due to other causes (10).

Monnier recommends that, when dealing with soft-tissue stenosis without mucosal necrosis, a re-intubation should be performed with a one-size smaller endotracheal tube with topical application of an endolaryngeal plug of gentamycincorticosteroid ointment. Most of these patients can be extubated after a mean re-intubation period of 2-4 days (11).

\section{Endoscopic Balloon Dilation (EBD)}

Balloon dilation was first described in 1984 as a method to treat tracheal and bronchial stenosis (12) Subsequently, other case reports were published (13-15). All of them, however, applied balloon dilation for patients with chronic stenoses. The analysis of balloon dilation results for chronic and acute stenoses as separate diseases was only recently attempted.

Compared to previous methods of dilation such as bougies and endotracheal tubes, this new technique has the theoretical advantage of exerting radial pressure on the airway, which projects the stenosis away from the center of the airway, reducing the incidence of shear-related trauma of the epithelium that may occur with rigid dilation (16). Balloon dilation has been studied in several case series since 1991, but its indications, safety and efficacy were still under debate.

The literature search identified 24 abstracts about balloon dilation. After review of the full-length articles, 14 were excluded, due to its use for chronic stenoses $(15,17-20)$, due to its lack of differentiation between acute or chronic stenosis (16, 19, 21-27), and/or because the paper did not differentiate between rigid or balloon dilations $(27,28)$. The 10 remaining papers were selected for this review $(3,29-37)$.

\section{Technique}

Balloon dilation is performed under general anesthesia in all articles, using a high pressure, non-compliant balloon catheter. The technique has a slight variability in the studies.

Some authors used the INSPIRA AIRTM balloon (Acclarent Inc., CA, U.S.A.) $(33,37)$. Other authors do not mention the brands of their balloons and/or use many different brands (3, 29$32,34-36)$. The balloon size was selected according to the ideal subglottic diameter for the patient's age $(3,29,32-34,36,37)$. An inflation/deflation handle mounted with a syringe and gauge assembly designed to monitor and maintain the pressure was used by all authors (29-38). The balloon was inflated to rated burst pressure by some authors $(33,36,37)$. Other authors specifically mentioned pressures between 2 and $15 \mathrm{~atm}$, (3) $2 \mathrm{~atm}$, $(29,31,34), 4 \mathrm{~atm},(32), 7 \mathrm{~atm}(30)$. The balloon was maintained inflated for 30-60 s or until the patient's oxygen saturation level dropped below $90-92 \%(3,29-37)$. Some authors repeated the procedure 2-3 times during each session (31-37).

\section{Outcomes of Balloon Dilation}

The 10 case reports and series (nine retrospectives, one prospective), published between 2007 and 2017, included 109 pediatric patients who underwent 1-6 dilations each, with an average 1.8 dilations per patient. Follow-up ranged from 5 days to 7 years $(3,29-37)$. Included studies are summarized on Table 3.

Success was defined as an improvement of symptoms, decrease in Myer-Cotton level of stenosis, decannulation of previous tracheostomy, or avoidance of reconstructive surgeries and tracheostomy in all studies. Success rate ranged from 66 to $100 \%$, with a total of 97 of the 109 patients (88.99\%) reaching a successful outcome.

None of the studies described complications of the procedure. Avelino et al. described that four patients presented dysphagia in the post-operative period, but they do not specify whether these patients had previous acute or chronic SGS (3).

\section{Balloon Adjunctive Treatments Mitomycin-C}

Mitomycin-C is an antibiotic produced by Strepnomyces caespitosus exhibiting antiproliferative and antineoplastic properties. It inhibits fibroblast proliferation and synthesis of extracellular matrix proteins, and thereby modulates wound healing and scarring.

Ortiz et al. described 16 children presenting SGS managed with balloon dilation and topical application of mitomycin solution $1 \mathrm{mg} / \mathrm{mL}$ in the dilated area for $1 \mathrm{~min}$, reporting a $100 \%$ success rate. Authors describe that laryngoscopy was performed as soon as symptoms appeared, but do not specify the time interval between extubation and examination. Mean number of dilation procedures was 2.5 , and the number of sessions was proportional to the grade of stenosis (39). 

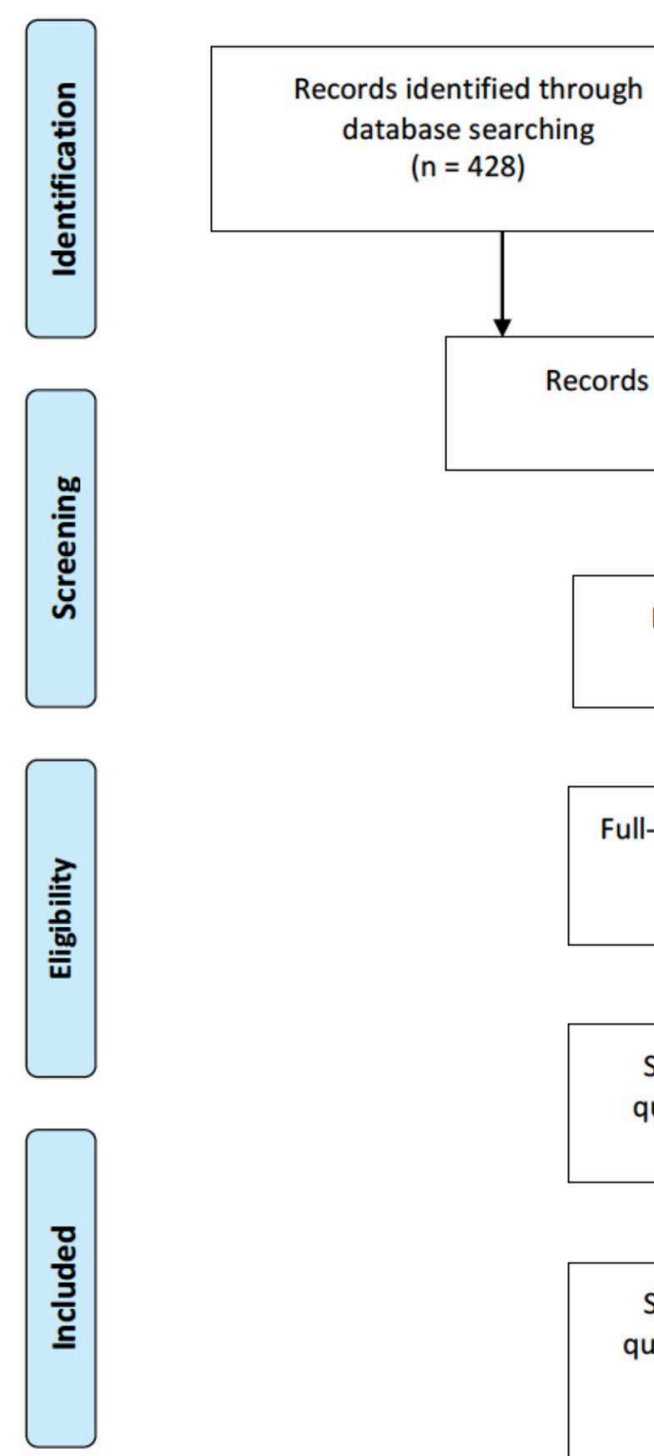

Additional records identified through other sources $(n=4)$

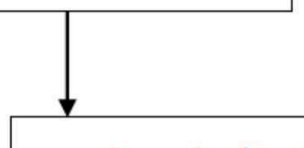

Records after duplicates removed ( $n=432$ )
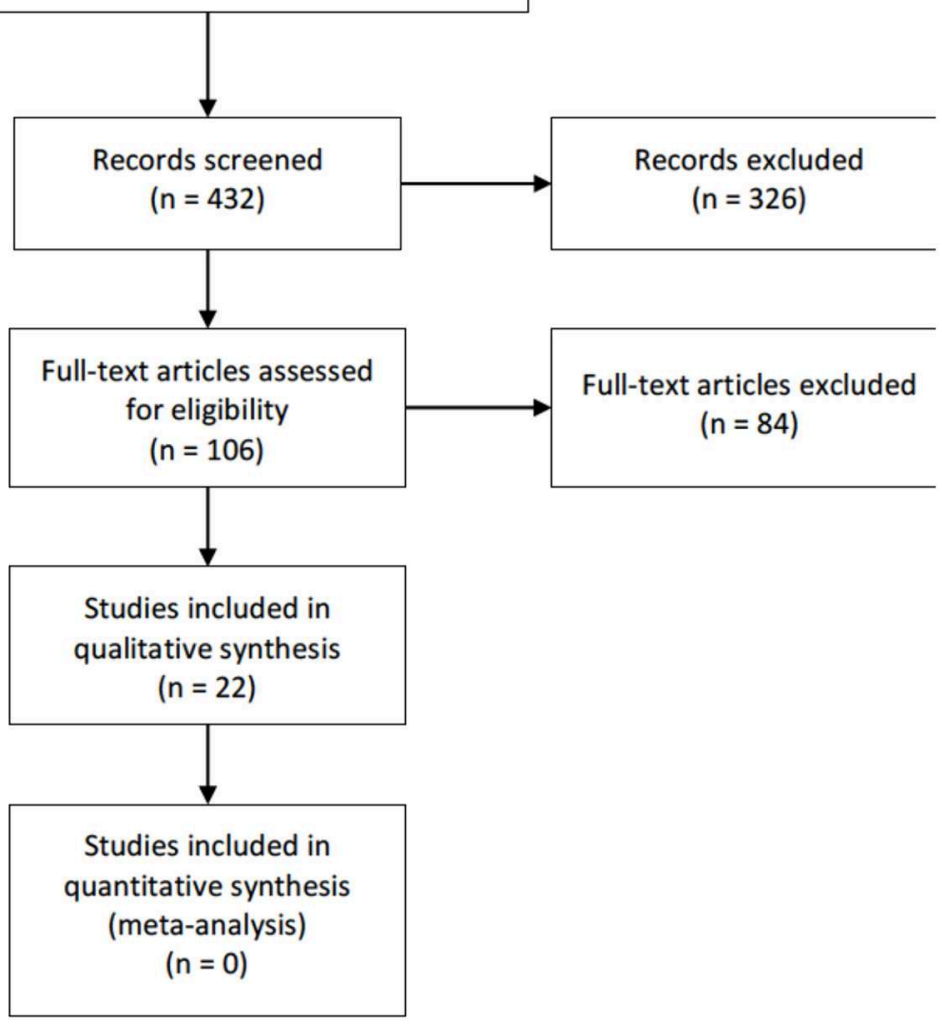

FIGURE 1 | PRISMA flow diagram.

\section{Endoscopic Anterior Cricoid Split (EACS)}

Open surgical approach was first described by Cotton as an alternative to performing tracheotomy in premature infants with prolonged intubation. As the aim of the present review is conservative treatments, only EACS is reviewed.

Mirabile et al. (40) described for the first time EBD-associated EACS. They reported five acquired stenosis patients without tracheostomy in whom a $100 \%$ success rate was attained. After this first study, Chen et al. (36) described three children presenting acute SGS undergoing EBD + EACS with a success rate of $66.7 \%$. Similarly, Horn et al. (41) described success with the technique in two out of three children presenting extubation failure. Carr et al. (42) described a 100\% success rate in five intubated children with extubation failure, using this same approach.

\section{Rigid Dilation}

The literature search identified 14 abstracts about rigid dilation. After review of the full-length articles, only one of those studies clearly separated acute and chronic lesion groups, which was eventually included (4).

Dilations were performed with increasing diameter endotracheal tubes, depending on the patient's age. Dilation was started with Silastic (a portmanteau of "silicone"and "plastic") bougies when stenosis prevented the introduction of a $2.5 \mathrm{~mm}$ endotracheal tubes. In 12 patients, adjuvant treatment was administered locally, but authors did not separate groups (acute or chronic) for this intervention. Success rate was $96.4 \%$ (27/28) and researchers determined that acute stenosis was a predictor of success, while chronic stenosis showed a success rate of $57.1 \%$. 
TABLE 3 | Balloon dilation: case reports and case series $(n=109)$.

\begin{tabular}{|c|c|c|c|c|c|}
\hline $\begin{array}{l}\text { Author, year. } \\
\text { Retrospective X } \\
\text { prospective }\end{array}$ & $\begin{array}{l}\text { Number of patients. } \\
\text { Age }\end{array}$ & $\begin{array}{l}\text { Description of the type } \\
\text { of SGS. Grade of SGS }\end{array}$ & $\begin{array}{l}\text { Number of dilations. } \\
\text { Mean number of } \\
\text { dilations per patient }\end{array}$ & Adjuvant treatment & $\begin{array}{l}\text { Success rate. Follow-up } \\
\text { length }\end{array}$ \\
\hline $\begin{array}{l}\text { Durden and Sobol (29). } \\
\text { Retrospective case } \\
\text { series }\end{array}$ & $\begin{array}{l}\text { Four patients. } \\
3-7 \text { mo }\end{array}$ & $\begin{array}{l}\text { Soft. } \\
\text { Grades 2-3 }\end{array}$ & $\begin{array}{l}\text { 1-2 dilations per patient. } \\
\text { Mean: } 1.2\end{array}$ & $\begin{array}{l}\text { Topical steroid applied } \\
\text { + intubation for } 24-48 \mathrm{~h} \\
+ \text { systemic steroid }\end{array}$ & $\begin{array}{l}75 \% \text { success. }^{a} \\
\text { Mean of } 3.5 \text { months of } \\
\text { follow-up }\end{array}$ \\
\hline $\begin{array}{l}\text { Rossetti et al. (30). } \\
\text { Retrospective case } \\
\text { report }\end{array}$ & $\begin{array}{l}\text { One patient. } \\
10 \mathrm{mo}\end{array}$ & $\begin{array}{l}\text { Acute. } \\
\text { Grade } 3\end{array}$ & 1 dilation. & None & $\begin{array}{l}100 \% \text { success. } \\
5 \text { days of follow-up }\end{array}$ \\
\hline $\begin{array}{l}\text { Schweiger et al. (31). } \\
\text { Prospective case series }\end{array}$ & $\begin{array}{l}\text { Eight patients. } \\
2-14 \text { mo }\end{array}$ & $\begin{array}{l}\text { Acute }(<60 \text { days after } \\
\text { intubation, with GT). } \\
\text { Grades } 1-3\end{array}$ & $\begin{array}{l}1-2 \text { dilations per patient. } \\
\text { Mean: } 1.37 \text { dilations per } \\
\text { patient }\end{array}$ & Systemic steroids & $\begin{array}{l}100 \% \text { success. } \\
6 \text { months of follow-up }\end{array}$ \\
\hline $\begin{array}{l}\text { Collins et al. (32). } \\
\text { Retrospective case } \\
\text { series }\end{array}$ & $\begin{array}{l}\text { Two patients. } \\
1 \text { mo (both) }\end{array}$ & $\begin{array}{l}\text { Thin, circumferential SGS. } \\
\text { Grade } 3\end{array}$ & $\begin{array}{l}2 \text { dilations. } \\
\text { Mean: } 1\end{array}$ & $\begin{array}{l}\text { Topical Mitomycin ( } 1 \\
\text { patient) and topical } \\
\text { triamcinolone ( } 1 \\
\text { patient) }\end{array}$ & $\begin{array}{l}100 \% \text { success. } \\
1-23 \text { months of follow-up }\end{array}$ \\
\hline $\begin{array}{l}\text { Whigham et al. (33). } \\
\text { Retrospective case } \\
\text { series }\end{array}$ & $\begin{array}{l}\text { Nine patients. }^{c} \\
1-31 \text { mo } \\
\text { (mean }=10.8 \mathrm{mo})\end{array}$ & $\begin{array}{l}\text { Soft. } \\
\text { Grade 2-3 }\end{array}$ & $\begin{array}{l}14 \text { dilations. } \\
\text { Mean: } 1.55 \text { per patient }\end{array}$ & None & $\begin{array}{l}66 \% \text { success. } \\
12-24 \text { months of follow-up }\end{array}$ \\
\hline $\begin{array}{l}\text { Filiz and Ulualp (34). } \\
\text { Retrospective case } \\
\text { series }\end{array}$ & $\begin{array}{l}\text { Three patients. } \\
14 \text { weeks- } 1 \text { yo }\end{array}$ & $\begin{array}{l}\text { Acute ( } 5 \text { days to } 6 \text { weeks } \\
\text { after extubation). } \\
\text { Grades } 2-3\end{array}$ & $\begin{array}{l}\text { 3-4 dilations per patient. } \\
\text { Mean: } 3.33 \text { per patient }\end{array}$ & Systemic steroids & $\begin{array}{l}100 \% \text { success. } \\
14-21 \text { months of follow-up }\end{array}$ \\
\hline $\begin{array}{l}\text { Avelino et al. (3). } \\
\text { Retrospective }\end{array}$ & $\begin{array}{l}17 \text { patients. }^{d} \\
\text { Mean: } 4.2 \text { mo }\end{array}$ & $\begin{array}{l}\text { Acute }(<30 \text { days after } \\
\text { extubation). } \\
\text { Grades } 1-3\end{array}$ & $\begin{array}{l}\text { Mean: } 2 \text { dilations per } \\
\text { patient. }\end{array}$ & $\begin{array}{l}\text { Oral prednisolone + } \\
\text { steroid nebulization }\end{array}$ & $\begin{array}{l}100 \% \text { success. } \\
3-15 \text { months of follow-up } \\
\text { (mean } 7.8 \text { months) }\end{array}$ \\
\hline $\begin{array}{l}\text { Ozturk et al. (35). } \\
\text { Retrospective case } \\
\text { report }\end{array}$ & $\begin{array}{l}\text { One patient. } \\
23 \text { days-old }\end{array}$ & $\begin{array}{l}\text { Acute. } \\
\text { Grade } 3\end{array}$ & 2 dilations. & & $\begin{array}{l}100 \% \text { success. } \\
8 \text { months of follow-up }\end{array}$ \\
\hline $\begin{array}{l}\text { Alshammari et al. (37). } \\
\text { Retrospective }\end{array}$ & $\begin{array}{l}45 \text { patients. }^{e} \\
1 \text { mo-15 yo }\end{array}$ & $\begin{array}{l}40 \text { soft, } 5 \text { mature. } \\
\text { Grades 1-3 }\end{array}$ & $\begin{array}{l}1-6 \text { dilations per patient. } \\
\text { Mean: } 2\end{array}$ & 1-2 ml Kenalog & $\begin{array}{l}82.3 \% \text { success. } \\
1 \text { year of follow-up }\end{array}$ \\
\hline $\begin{array}{l}\text { Chen et al. (36). } \\
\text { Retrospective }\end{array}$ & $\begin{array}{l}19 \text { patients. }^{\dagger} \\
0.3-144 \text { mo } \\
\text { (mean = } 4 \text { mo) }\end{array}$ & $\begin{array}{l}\text { Acute. } \\
\text { Grades 2-4. }\end{array}$ & $\begin{array}{l}\text { 1-8 dilations per patient. } \\
\text { Mean: } 2.6 \text { per patient }\end{array}$ & & $\begin{array}{l}100 \% \text { success. } \\
0.5-7 \text { years of follow-up }\end{array}$ \\
\hline
\end{tabular}

mo, months-old; yo, years-old; SGS, subglottic stenosis; GT, granulation tissue.

a One patient in the study needed a tracheostomy.

${ }^{b}$ Only patients number two and four were included in this analysis (not clearly described in the paper if the other three patients presented acute or chronic lesions).

${ }^{c}$ Only nine patients with soft stenosis and primary balloon dilation (excluded those who underwent adjuvant balloon dilation and those who had firm lesions).

${ }^{d}$ Only patients with acute lesions were included in this analysis.

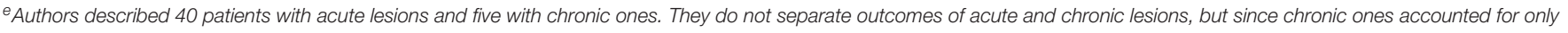
$12.5 \%$ of their patients, it was decided to include all their patients in this analysis.

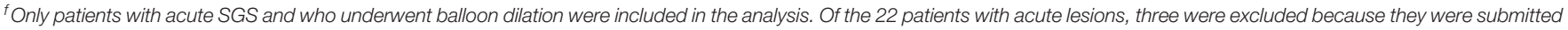
to balloon dilation + endoscopic anterior cricoid split.

\section{$\mathrm{CO}_{2}$ Laser and Coblation}

Studies concerning different laser and coblation techniques in laryngeal stenosis deal mainly with chronic stenosis (43-46). Regarding acute lesions, a study by Koufman et al. (47) was found describing five non-tracheostomized patients undergoing stenosis treatment with carbon dioxide $\left(\mathrm{CO}_{2}\right)$ surgical laser. Two of them needed tracheostomy, but eventually were decannulated. Dilation and steroid injection were adjunctive measures. Bollig and Gov-Ari (48) described a 9-monthsold girl successfully managed with bipolar radiofrequency plasma ablation (coblation) after prior multiple endoscopic balloon dilations.

\section{Microdebrider}

Rees et al. (49) described one case of subglottic granulation treated with microdebrider. This was the sole publication reporting the use of this technique in acute lesions.

\section{DISCUSSION}

In 1984, Cotton stated that endoscopic techniques were effective in the early phases of wound healing, when the scar tissue is soft and pliable (50). Since then, many techniques have been described, with variable rates of success. Recent technological advances have facilitated endoscopic approaches that promise fewer wound complications, decreased postoperative pain, shortened hospital stays, and no external scarring (40). The success of endoscopic techniques for acute stenosis is defined by the long-term resolution of stenosis and the avoidance of open surgery such as laryngotracheal reconstruction.

Rigid dilations have been used for a long time, with highly variable and essentially disappointing results $(51,52)$. Rigid dilation studies found in this review do not report clear inclusion criteria especially concerning mature or in evolution stenosis status. Also, miscellaneous etiologies and different age groups were enrolled. Furthermore, reported dilatation techniques and 
TABLE 4 | Comparison of therapeutic approaches success rates.

\begin{tabular}{lc}
\hline Therapeutic option in acute laryngeal lesions & Success rates $^{*}$ \\
\hline Elective endotracheal intubation & $60(10)-95.6 \%(9)$ \\
EBD & $66(33)-100 \%(36)$ \\
EBD + mitomycin-C & $100 \%(39)$ \\
EBD + EACS & $66.7(36)-100 \%(40)$ \\
Rigid dilation & $96.4 \%(4)$ \\
$\mathrm{CO}_{2}$ laser & $60 \%(47)$ \\
$\mathrm{Coblation}_{\text {Microdebrider }}$ & 1 successful case (48) \\
\hline
\end{tabular}

EBD, Endoscopic Balloon Dilation; EACS, Endoscopic Anterior Cricoid Split.

${ }^{*}$ Included studies did not report on complications rates from therapeutic approaches.

ancillary treatments are heterogeneous. It is known that although this technique is effective, significant sheer forces are generated across the area of stenosis, and ongoing serial dilatations are often required. Studies on rigid dilation showed the need of a high number of repeated dilations but again did not segregate chronic from acute lesions. The only one found stratifying this information reported a mean number of procedures of two and a success rate of $96.4 \%$.

Balloon dilation emerged as a promising alternative to those dilations with bougies, bronchoscopes and endotracheal tubes. It was initially designed for endovascular interventions and later adapted for use in tracheobronchial stenoses by interventional radiologists and pediatric surgeons $(12,13)$. The absence of shearing forces minimizes subglottic trauma, both at the mucosal level and in deeper planes, thereby decreasing the tendency to re-stenosis. As with conventional dilation techniques, balloon dilation is more likely to succeed in the presence of immature scar tissue (15).

While the number of reports on balloon dilation is still currently small, encouraging reports of this simple technique suggest that balloon dilation is probably the single most promising treatment for acute subglottic stenosis.

There is very little information available in the literature to guide balloon sizing, inflation pressure and length of inflation time. Currently, surgeons often use their own breadth of experience to guide the parameters used in the procedure. Excessively high inflation pressures or big balloon sizes can damage or rupture the airway, and inadequately low pressures or small balloon sizes can reduce the effectiveness of procedures and result in the requirement for even more procedures.

Lee et al. (28) was excluded of the balloon dilation analysis, but interestingly its results showed that, independently of the kind of therapy (bougination, incision using cold knife or laser, and balloon dilation), the success rate for acute SGS (within 30 days after extubation) is $88.8 \%$, compared to $9.09 \%$ for chronic stenosis (more than 30 days after extubation). Their success rate sharply equals the success rate of this systematic review (88.99\%). In the discussion, authors mention that the success rate is probably related to the SGS grade and nature of the scar tissue, since fine membranous scars and acute membranous type of SGS (immature scar tissue) can be expanded more easily than total cartilaginous fibrosis (mature scar tissue).

However, since the outcome of the dilation was not $100 \%$ in many studies, adjuvant therapies, such as steroid local injection, systemic steroids have been added to the therapeutic options in some cases. As we could notice in this systematic review, evidences about these adjuvant therapies are scarce. Also concerning other approaches such as $\mathrm{CO}_{2}$ laser, coblation and microdebridor, further studies are necessary in acute lesions to settle debate over those specific treatments.

The establishment of endoscopic management protocols is complex due to technique variability and multiplicity among different institutions and patient's individual characteristics. Success of endoscopic treatment is probably also significantly influenced by the skill and ability of the collaborative staff, especially anesthesiologists and neonatal/pediatric critical care specialists. Table 4 summarizes success rates from therapeutic approaches discussed in this review.

As far as authors are concerned, if the acute lesion is restricted to subglottis, EBD is the best option. In the postoperative period, steroid nebulization and proton pump inhibitor use has become a promising adjuvant treatment. Review laryngoscopy around the seventh postoperative day should always be performed, or even earlier if symptoms become noticeable. Procedure may be repeated many times, as long as the subglottic lumen is improving with each dilation. If the lumen is still not good enough after the second dilation, adjuvant treatment as topic steroids are advisable. Authors do not recommend more than 4 dilations-if the patient would require more than 4 dilations, it seems reasonable to change the therapeutic approach. When there is an associated glottic lesion or widespread airway edema or granulation tissue, reintubation with a one-or two-size smaller endotracheal tube with topical application of a steroid ointment for $48-72 \mathrm{~h}$ seems to be an attractive approach. Soon after extubation, we also recommend the use of inhaled corticosteroid and proton pump inhibitor.

Future studies should examine the effects of different balloon diameters and pressures, the role of adjuvant therapies such as steroid local injections and systemic steroids, and also the difference between rigid and balloon dilation. There are currently no evidence-based guidelines for the treatment of postintubation acute laryngeal lesions, and the clinical experience of each team often guides the therapeutic approach.

\section{DATA AVAILABILITY STATEMENT}

The raw data supporting the conclusions of this article will be made available by the authors, without undue reservation, to any qualified researcher.

\section{AUTHOR CONTRIBUTIONS}

CS and DM participated in study design, search strategy elaboration, peer-review, narrative review, manuscript writing, and final revision. 


\section{REFERENCES}

1. Schweiger C, Manica D, Pereira DRR, Carvalho PRA, Piva JP, Kuhl G, et al. Undersedation is a risk factor for the development of subglottic stenosis in intubated children. J Pediatr. (2017) 93:351-5. doi: 10.1016/j.jped.2016. 10.006

2. Manica D, Schweiger C, Marostica PJ, Kuhl G, Carvalho PR. Association between length of intubation and subglottic stenosis in children. Laryngoscope. (2013) 123:1049-54. doi: 10.1002/lary.23771

3. Avelino M, Maunsell R, Jube Wastowski I. Predicting outcomes of balloon laryngoplasty in children with subglottic stenosis. Int J Pediatr Otorhinolaryngol. (2015) 79:532-6. doi: 10.1016/j.ijporl.2015.01.022

4. Cuestas G, Rodriguez V, Doormann F, Bellia Munzon P, Bellia Munzon G. Endoscopic treatment of acquired subglottic stenosis in children: predictors of success. Arch Argent Pediatr. (2018) 116:418-25. doi: 10.5546/aap.2018.eng.422

5. Schweiger C, Manica D, Kuhl G, Sekine L, Marostica PJ. Post-intubation acute laryngeal injuries in infants and children: a new classification system. Int $J$ Pediatr Otorhinolaryngol. (2016) 86:177-82. doi: 10.1016/j.ijporl.2016.04.032

6. Rutter MJ, Cohen AP, De Alarcon A. Endoscopic airway management in children. Curr Opin Otolaryngol Head Neck Surg. (2008) 16:525-9. doi: 10.1097/MOO.0b013e3283184479

7. Hutton B, Salanti G, Caldwell DM, Chaimani A, Schmid CH, Cameron C, et al. The PRISMA extension statement for reporting of systematic reviews incorporating network meta-analyses of health care interventions: checklist and explanations. Ann Intern Med. (2015) 162:777-84. doi: 10.7326/M14-2385

8. Shamseer L, Moher D, Clarke M, Ghersi D, Liberati A, Petticrew M, et al. Preferred reporting items for systematic review and meta-analysis protocols (PRISMA-P) 2015: elaboration and explanation. BMJ. (2015) 349:g7647. doi: $10.1136 /$ bmj.g7647

9. Hoeve LJ, Eskici O, Verwoerd CD. Therapeutic reintubation for postintubation laryngotracheal injury in preterm infants. Int $J$ Pediatr Otorhinolaryngol. (1995) 31:7-13. doi: 10.1016/0165-5876(94)01061-2

10. Graham JM. Formal reintubation for incipient neonatal subglottic stenosis. $J$ Laryngol Otol. (1994) 108:474-8. doi: 10.1017/S0022215100127148

11. Monnier P, Bernath MA, Chollet-Rivier M, Cotting J, George M, Perez MH. Pediatric Airway Surgery: Management of Laryngotracheal Stenosis in Infants and Children Lausanne: Springer.

12. Cohen MD, Weber TR, Rao CC. Balloon dilatation of tracheal and bronchial stenosis. AJR Am J Roentgenol. (1984) 142:477-8. doi: 10.2214/ajr.142.3.477

13. Hebra A, Powell DD, Smith CD, Othersen HBJr. Balloon tracheoplasty in children: results of a 15-year experience. J Pediatr Surg. (1991) 26:957-61. doi: 10.1016/0022-3468(91)90843-I

14. Elkerbout SC, Van Lingen RA, Gerritsen J, Roorda RJ. Endoscopic balloon dilatation of acquired airway stenosis in newborn infants: a promising treatment. Arch Dis Child. (1993) 68:37-40. doi: 10.1136/adc.68.1_Spec_No.37

15. Axon PR, Hartley C, Rothera MP. Endoscopic balloon dilatation of subglottic stenosis. J Laryngol Otol. (1995) 109:876-9. doi: 10.1017/S0022215100131561

16. Wentzel JL, Ahmad SM, Discolo CM, Gillespie MB, Dobbie AM, White DR. Balloon laryngoplasty for pediatric laryngeal stenosis: case series and systematic review. Laryngoscope. (2014) 124:1707-12. doi: 10.1002/lary.24524

17. Gungor A. Balloon dilation of the pediatric airway: potential for disaster. Am J Otolaryngol. (2012) 33:147-9. doi: 10.1016/j.amjoto.2011.05.004

18. Guarisco JL, Yang CJ. Balloon dilation in the management of severe airway stenosis in children and adolescents. J Pediatr Surg. (2013) 48:1676-81. doi: 10.1016/j.jpedsurg.2012.12.035

19. Gunaydin RO, Suslu N, Bajin MD, Kuscu O, Yilmaz T, Unal OF, et al. Endolaryngeal dilatation versus laryngotracheal reconstruction in the primary management of subglottic stenosis. Int J Pediatr Otorhinolaryngol. (2014) 78:1332-6. doi: 10.1016/j.ijporl.2014.05.022

20. Lisy J, Groh D, Chovanec M, Markova M, Suchanek V, Polaskova P, et al. Balloon dilatation of pediatric subglottic laryngeal stenosis during the artificial apneic pause: experience in 5 children. Biomed Res Int. (2014) 2014:397295. doi: $10.1155 / 2014 / 397295$

21. Bent JP, Shah MB, Nord R, Parikh SR. Balloon dilation for recurrent stenosis after pediatric laryngotracheoplasty. Ann Otol Rhinol Laryngol. (2010) 119:619-27. doi: 10.1177/000348941011900909
22. Hautefort C, Teissier N, Viala P, Van Den Abbeele T. Balloon dilation laryngoplasty for subglottic stenosis in children: 8 years' experience. Arch Otolaryngol Head Neck Surg. (2012) 138:235-40. doi: 10.1001/archoto.2011.1439

23. Maturo SC, Hartnick CJ. Pediatric airway balloon dilation. $A d v$ Otorhinolaryngol. (2012) 73:112-5. doi: 10.1159/000334461

24. Chueng K, Chadha NK. Primary dilatation as a treatment for pediatric laryngotracheal stenosis: a systematic review. Int J Pediatr Otorhinolaryngol. (2013) 77:623-8. doi: 10.1016/j.ijporl.2013.02.003

25. Maresh A, Preciado DA, O'connell AP, Zalzal GH. A comparative analysis of open surgery vs endoscopic balloon dilation for pediatric subglottic stenosis. JAMA Otolaryngol Head Neck Surg. (2014) 140:901-5. doi: 10.1001/jamaoto.2014.1742

26. Talwar R, Virk JS, Bajaj Y. Paediatric subglottic stenosis-have things changed? Our experience from a developing tertiary referral centre. Int $J$ Pediatr Otorhinolaryngol. (2015) 79:2020-2. doi: 10.1016/j.ijporl.2015.08.031

27. Bavishi A, Boss E, Shah RK, Lavin J. Outcomes after endoscopic dilation of laryngotracheal stenosis: an analysis of ACS-NSQIP. J Clin Outcomes Manag. (2018) 25:111-6.

28. Lee JC, Kim MS, Kim DJ, Park DH, Lee IW, Roh HJ, et al. Subglottic stenosis in children: our experience at a pediatric tertiary center for 8 years in South Korea. Int J Pediatr Otorhinolaryngol. (2019) 121:64-7. doi: 10.1016/j.ijporl.2019.02.044

29. Durden F, Sobol SE. Balloon laryngoplasty as a primary treatment for subglottic stenosis. Arch Otolaryngol Head Neck Surg. (2007) 133:772-5. doi: 10.1001/archotol.133.8.772

30. Rossetti E, Germani A, Onofri A, Bottero S. Non-invasive ventilation with balloon dilatation of severe subglottic stenosis in a 10-months infant. Intensive Care Med. (2011) 37:364-5. doi: 10.1007/s00134-010-2069-0

31. Schweiger C, Smith MM, Kuhl G, Manica D, Marostica PJ. Balloon laryngoplasty in children with acute subglottic stenosis: experience of a tertiary-care hospital. Braz J Otorhinolaryngol. (2011) 77:711-5. doi: 10.1590/S1808-86942011000600006

32. Collins WO, Kalantar N, Rohrs HB, Silva RC. The effects of balloon dilation laryngoplasty in children with congenital heart disease. Arch Otolaryngol Head Neck Surg. (2012) 138:1136-40. doi: 10.1001/jamaoto.2013.676

33. Whigham AS, Howell R, Choi S, Pena M, Zalzal G, Preciado D. Outcomes of balloon dilation in pediatric subglottic stenosis. Ann Otol Rhinol Laryngol. (2012) 121:442-8. doi: 10.1177/000348941212100704

34. Filiz A, Ulualp SO. Long-term outcomes of balloon dilation for acquired subglottic stenosis in children. Case Rep Otolaryngol. (2014) 2014:304593. doi: $10.1155 / 2014 / 304593$

35. Ozturk K, Erdur O, Sofiyev F, Onal IO, Annagur A. Non-invasive treatment of acquired subglottic stenosis. J Craniofac Surg. (2016) 27:e492-3. doi: $10.1097 /$ SCS.0000000000002809

36. Chen C, Ni WH, Tian TL, Xu ZM. The outcomes of endoscopic management in young children with subglottic stenosis. Int J Pediatr Otorhinolaryngol. (2017) 99:141-5. doi: 10.1016/j.ijporl.2017.06.012

37. Alshammari J, Alkhunaizi AA, Arafat AS. Tertiary center experience with primary endoscopic laryngoplasty in pediatric acquired subglottic stenosis and literature review. Int J Pediatr Adolesc Med. (2017) 4:33-7. doi: 10.1016/j.ijpam.2016.11.001

38. Avelino MG, Fernandes EJ. Balloon laryngoplasty for subglottic stenosis caused by orotracheal intubation at a tertiary care pediatric hospital. Int Arch Otorhinolaryngol. (2014) 18:39-42. doi: 10.1055/s-0033-1358577

39. Ortiz R, Dominguez E, De La Torre C, Hernandez F, Encinas JL, LopezFernandez S, et al. Early endoscopic dilation and mitomycin application in the treatment of acquired tracheal stenosis. Eur J Pediatr Surg. (2014) 24:39-45. doi: $10.1055 / \mathrm{s}-0033-1357754$

40. Mirabile L, Serio PP, Baggi RR, Couloigner VV. Endoscopic anterior cricoid split and balloon dilation in pediatric subglottic stenosis. Int $J$ Pediatr Otorhinolaryngol. (2010) 74:1409-14. doi: 10.1016/j.ijporl.2010.09.020

41. Horn DL, Maguire RC, Simons JP, Mehta DK. Endoscopic anterior cricoid split with balloon dilation in infants with failed extubation. Laryngoscope. (2012) 122:216-9. doi: 10.1002/lary.22155

42. Carr S, Dritsoula A, Thevasagayam R. Endoscopic cricoid split in a tertiary referral paediatric centre. J Laryngol Otol. (2018) 132:753-6. doi: $10.1017 /$ S0022215118001226 
43. Duncavage JA, Ossoff RH, Toohill RJ. Carbon dioxide laser management of laryngeal stenosis. Ann Otol Rhinol Laryngol. (1985) 94:565-9. doi: $10.1177 / 000348948509400608$

44. Zawadzka-Glos L, Chmielik M, Gabryszewska A. The endoscopic treatment of postintubation laryngeal stenosis in children, using argon plasma coagulation. Int J Pediatr Otorhinolaryngol. (2003) 67:609-12. doi: 10.1016/S0165-5876(03)00064-8

45. Monnier P, George M, Monod ML, Lang F. The role of the CO2 laser in the management of laryngotracheal stenosis: a survey of 100 cases. Eur Arch Otorhinolaryngol. (2005) 262:602-8. doi: 10.1007/s00405-005-0948-8

46. Fastenberg JH, Roy S, Smith LP. Coblation-assisted management of pediatric airway stenosis. Int J Pediatr Otorhinolaryngol. (2016) 87:213-8. doi: 10.1016/j.ijporl.2016.06.035

47. Koufman JA, Thompson JN, Kohut RI. Endoscopic management of subglottic stenosis with the $\mathrm{CO}_{2}$ surgical laser. Otolaryngol Head Neck Surg. (1981) 89:215-20. doi: 10.1177/019459988108900214

48. Bollig CA, Gov-Ari E. A novel use of coblation in the treatment of subglottic stenosis. Int J Pediatr Otorhinolaryngol. (2018) 111:108-10. doi: 10.1016/j.ijporl.2018.05.023

49. Rees CJ, Tridico TI, Kirse DJ. Expanding applications for the microdebrider in pediatric endoscopic airway surgery. Otolaryngol Head Neck Surg. (2005) 133:509-13. doi: 10.1016/j.otohns.2005.06.029
50. Cotton RT, Myer CM 3rd. Contemporary surgical management of laryngeal stenosis in children. $\mathrm{Am} J$ Otolaryngol. (1984) 5:360-8. doi: 10.1016/S0196-0709(84)8 0006-X

51. Grahne B. Operative treatment of severe chronic traumatic laryngeal stenosis in infants up to 3 years old. Acta Otolaryngol. (1971) 72:134-7. doi: 10.3109/00016487109122465

52. Louhimo I, Grahne B, Pasila M, Suutarinen T. Acquired laryngotracheal stenosis in children. J Pediatr Surg. (1971) 6:730-7. doi: 10.1016/0022-3468(71)90853-0

Conflict of Interest: The authors declare that the research was conducted in the absence of any commercial or financial relationships that could be construed as a potential conflict of interest.

Copyright (c) 2020 Schweiger and Manica. This is an open-access article distributed under the terms of the Creative Commons Attribution License (CC BY). The use, distribution or reproduction in other forums is permitted, provided the original author(s) and the copyright owner(s) are credited and that the original publication in this journal is cited, in accordance with accepted academic practice. No use, distribution or reproduction is permitted which does not comply with these terms. 